\title{
金属材料の粉末技術〜鉄粉〜
}

\author{
高下 拓也*，宇波 繁 \\ JFE スチール (株)，％260-0835 千葉市中央区川崎町 1 番地.
}

\section{Powder Technology of Metal Materials Iron Powder}

\author{
Takuya TAKASHITA* and Shigeru UNAMI \\ Iron Powder \& Magnetic Materials Research Department, Steel Research Laboratory, JFE Steel Corporation, \\ 1 Kawasaki-cho, Chuo-ku, Chiba 260-0835, Japan.
}

Received April 27, 2020; Revised June 12, 2020; Accepted August 26, 2020

\begin{abstract}
Iron powder is one of the "long-seller" material because it has been used since B. C. 300. Iron powder is mainly used for powder metallurgy in recent years. On the other hands, it is also used for the functional applications by using chemical reaction, such as body warmer, deoxidant and agricultural application. There are the several methods to produce iron powder, and reduced and water atomized iron powders are mainly used for the powder metallurgy due to their good compactibilities. In this paper, the details of production process of iron powders containing alloyed steel powders in JFE steel, which produces both reduced and water atomized iron powders, are described. In addition, the powder characteristics of these two kinds of iron powders are also described. The expansion of functional applications such as additive manufacturing process or magnetic cores is expected in the future, thus additional improvement of iron powders quality will be required.
\end{abstract}

\section{KEY WORDS}

pure iron powder, water atomized iron powder, reduced iron powder

\section{1 はじめに}

鉄粉の初期の使用例は紀元前 300 年にインドのデリーに作 られた円柱にまで遡る ${ }^{1)}$.それから 2300 年経った近年でも， 鉄粉は用途，目的を変えて使われ続けており非常に息の長い 材料であると言える. 国内の 2016〜2018 年度の鉄粉出荷量 とその内訳を Fig. 1 に示す ${ }^{2)}$ が, 近年はその半数が粉末治金 用として出荷されていることが分かる．また，図中に明記さ れていない用途として，カイロや脱酸素剂，近年注目されて いる稲作向けの直播用鉄粉などがあり，適用先が構造材料だ けに留まらず，多くの機能材料にも亘る点も鉄粉の特徴の一 つであると言える。

鉄粉と一口に言っても，その製造方法には様々なものがあ る. 鉄粉の製造方法をまとめたものを Table 1 に示す ${ }^{3)}$. 鉄粉 の製造方法は，主として化学的反応法およびアトマイズ法に 大きく分類できる。それぞれの手法によって，得られる鉄粉 粒子の形状，粒子径等の粉末特性も大きく変化する. このう

* Corresponding author, E-mail: t-takashita@jfe-steel.co.jp
ち粉末治金用としては, 水アトマイズ法もしくは化学的反応 法の中の還元法によって得られる鉄粉が多く用いられてい る.この 2 つ方法によって得られる鉄粉は比較的不定形な 粒子形状をしており，鉄粉成形時に粒子同士が絡み合うた め，保形性が高く，焼結を行うまでの工程のハンドリングが

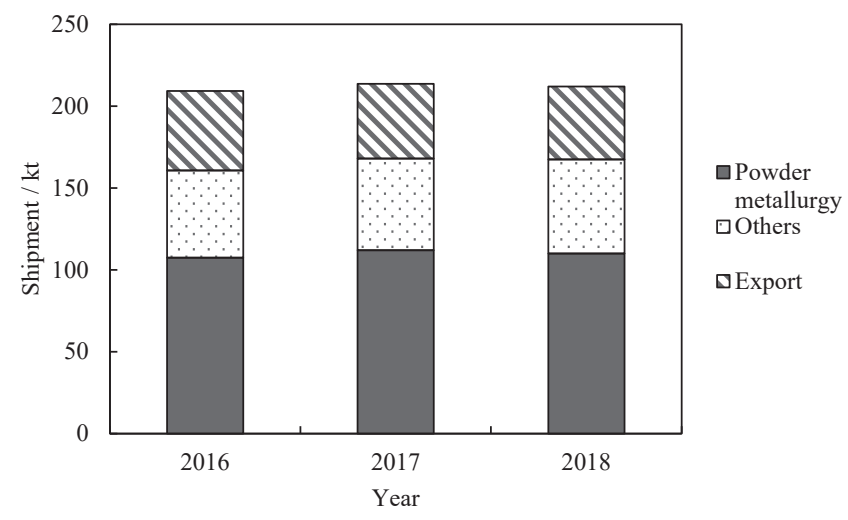

Fig. 1 Domestic production volume trend of iron powder ${ }^{2}$. 
Table 1 Several methods for producing iron powder.

\begin{tabular}{lll}
\hline Principle & Method & Mill scale \\
\hline \multirow{3}{*}{ Chemical reaction } & Reduction process & Iron ore \\
\hline & Electrolytic process \\
\hline Carbonyl process & \\
\hline \multirow{3}{*}{ Atomization } & Gas atomization process \\
\hline & Water atomization process \\
\hline & Centrifugal atomization process \\
\hline
\end{tabular}

容易なためである ${ }^{4)}$. 水アトマイズ法あるいは還元法で鉄粉 製造を行っているメーカーは国内に数社存在するが，両方の 方法で鉄粉を製造しているメーカーはJFEスチールのみ ある．本解説では鉄粉の中でも粉末治金用として消費量の多 い水アトマイズ鉄粉および還元鉄粉に着目し, JFE スチール での製造方法を例として各工程の詳細およびその製造方法に よって特徴づけられる各種鉄粉および合金鋼粉の粉体特性 や，それらを用いた焼結部品の特性について述べる.

\section{2 鉄粉の製造方法}

\section{1 製造工程概略}

JFE スチールにおける鉄粉の製造工程を Fig. 2 に示す ${ }^{6}$. 上 述のように，大きく分けて水アトマイズ鉄粉と還元鉄粉の 2 種類の製造プロセスが存在する。しかしながら，いずれも還 元熱処理以降の工程は共通化されており, 水アトマイズ工程 および海綿鉄（還元鉄）工程で製造されたそれぞれの原料鉄 粉は，還元工程で集約して処理する流れとなっている．還元 工程以降は, 必要に応じて混合や偏析防止処理を施した後に 出荷される．また，一部の用途では還元工程や偏析防止処理 工程を経ずにそのまま出荷されるものもある.

2.2 アトマイズ工程〜水アトマイズ鉄粉製造工程〜

アトマイズ工程の概略図を Fig. 3 に示す。まずは，溶解炉 にて所定の成分に調整した溶鋼をタンディッシュに注ぐ．溶 鋼の原料は一般的にはスクラップを溶解して用いることが多 いが, JFE スチールでは転炉溶鋼の一部を分湯して水アトマ イズに用いている。これによりスクラップ由来の不純物が極 めて少ない水アトマイズ粉の製造が可能となっている.

次に，タンディッシュ下部にある小孔より溶鋼を流出させ る.この溶鋼流に対して高圧の水ジェットを吹き付けること で, 溶鋼が粉砕, 急冷されて粉末が得られる. 水アトマイ ズ時の溶鋼の温度や流量, また溶鋼流に吹き付けられる水 ジェットの水圧, 流量および角度等によって得られる粉末の 特性が変化する．鉄粉メーカー各社のノウハウとなっている 部分も多く，具体的な数值は公表されていないが，例えば新 田ら ${ }^{7)}$ の検討では水ジェット水圧は 6 15 MPa 程度である. また, 水ジェットの形状についても逆円錐型ノズル方式, $\mathrm{V}$ ジェット方式, ペンシルジェット方式等, 種々の形が提案さ れている ${ }^{8)}$.

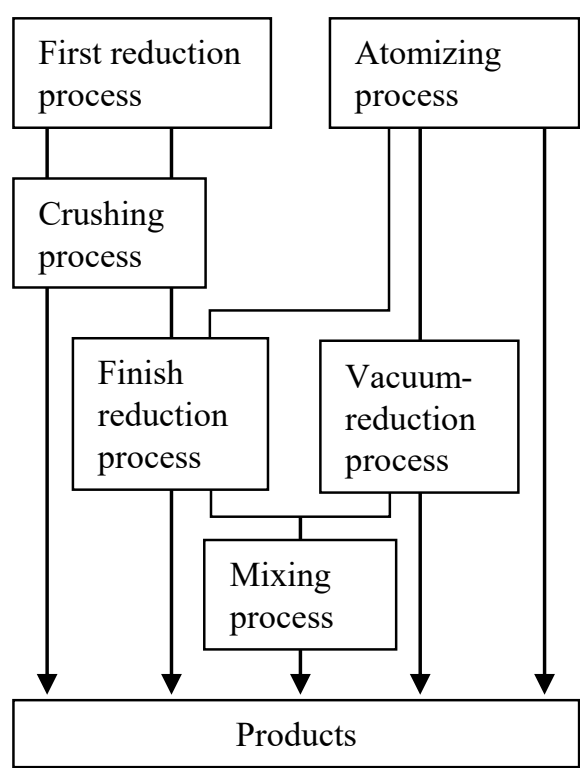

Fig. 2 Manufacturing process of iron powder and steel powder.

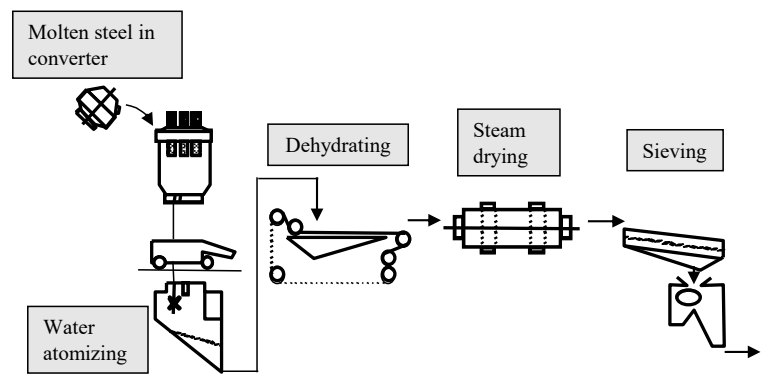

Fig. 3 Water atomizing process.

上述のようにして噴霧された粉末は噴霧槽内に水と混ざり 合ったスラリーの状態で堆積しており，ポンプで吸い上げら れて脱水・乾燥工程へ進む. スラリーは粉末中に含まれる水 分量が多く，一度の工程で乾燥させるのは困難である。その ため，脱水機によって水分を減少させたのちに，スチームド ライヤーで乾燥される . 乾燥後の粉末は篩分けによって所 定の粒度に分級され，次工程へ送られる。ここまでの工程で 得られた鉄粉のことをJFE スチールでは「生粉」と呼称して いる. 生粉は $1 \mathrm{mass} \%$ 未満の酸素と炭素を含み硬質なため, 


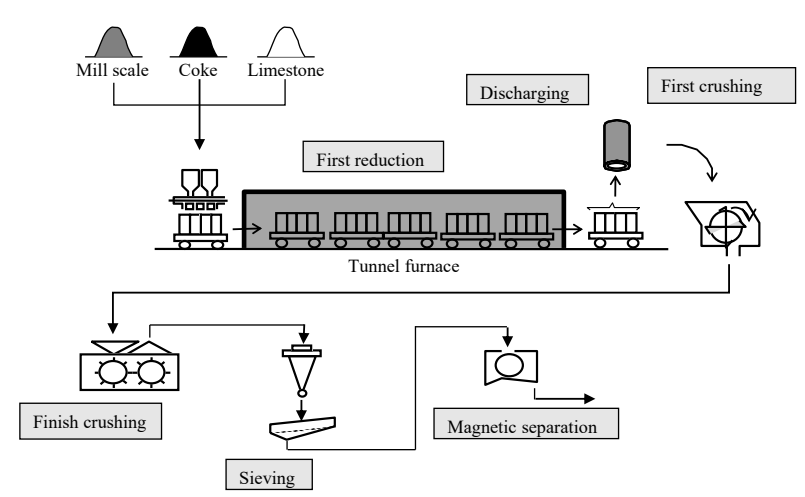

Fig. 4 First reduction and crushing process.

圧粉成形や焼結を行う粉末治金用途には不適であるが，化学 反応用途等に用いられることもある.

2.3 粗還元工程 還元鉄粉製造工程〜

還元鉄粉は酸化鉄を原料とした鉄粉である，そのため，還 元により酸化鉄中の酸素を還元する必要がある，原理上， 還元を後述の仕上還元工程にて 1 度で行うことも可能である が, 仕上還元工程での水素使用量が増加してしまう等の経済 的なデメリットがある。そそこで，水素による仕上還元を実施 する前に粗還元によりある程度の還元を行うのが一般的であ る. 粗還元工程の概略図を Fig. 4 に示す.

まずは, 原料の酸化鉄, 還元剂であるコークス抢よび脱硫 剤である石灰 $\left(\mathrm{CaCO}_{3}\right)$ をサガーと呼ばれる $\mathrm{SiC}$ 製耐熱容器 内に充填する。原料の酸化鉄として, JFE スチールではミル スケールを採用している。 ミルスケールとは，鋼板製造工程 に打ける熱間圧延工程でスラブや粗圧延後の鋼板表面に生じ た酸化鉄を，水ジェットで表面から除去した後に回収したも のである，元を辿れば転炉で精錬された溶鋼であるため，清 浄度が高いことが特徴である，その他，高純度の鉄鉱石を原 料として還元鉄粉を製造しているメーカーも存在する゙.

原料を充填された $\mathrm{SiC}$ 製耐熱容器は, 粗還元炉（トンネル 炉）へと挿入され, 約 $1100^{\circ} \mathrm{C} て ゙ 5$ 日間程度熱処理される.

この際の鉄の還元反応は酸化鉄とコークスの固相反応では なく，CO ガスによる還元反応が支配的であると言われてい る9!. CO ガスはコークスが酸化して生じる(1)のケースと, $\mathrm{CO}_{2}$ とコークスが反応して生じる (2)のケースの両方が考元 られているッ.

$$
\begin{aligned}
& 2 \mathrm{C}+\mathrm{O}_{2} \rightarrow 2 \mathrm{CO} \\
& \mathrm{C}+\mathrm{CO}_{2} \rightarrow 2 \mathrm{CO}
\end{aligned}
$$

脱硫剤として添加している石灰は熱分解で $\mathrm{CO}_{2}$ を生じる。 そ のため, 石灰も間接的に還元に寄与していると考えられる ${ }^{8)}$. $\mathrm{CO}$ と酸化鉄は (3) の反応で還元され, 純鉄が得られる.

$$
\mathrm{FeO}+\mathrm{CO} \rightarrow \mathrm{Fe}+\mathrm{CO}_{2}
$$

また，上記のような反応が進む一方で，COによる純鉄への 浸炭も同時に進行する。過度の浸炭は, 後工程での脱炭を困 難にするため, 本工程での還元は浸炭が過度に進行しないレ ベルで終了させることが必要である.

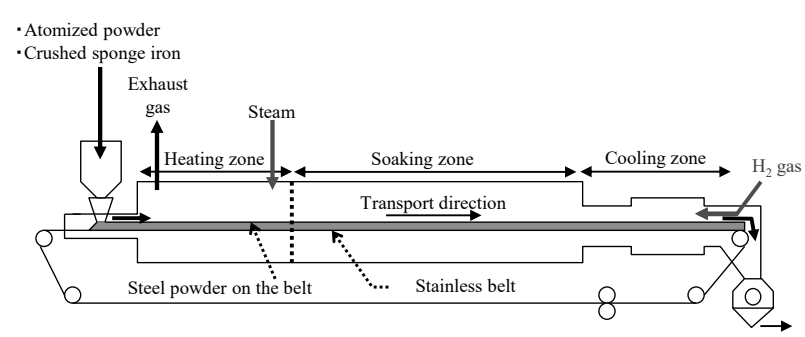

Fig. 5 The structure of finish reduction furnace.

トンネル炬通炉後に $\mathrm{SiC}$ 耐熱容器から取り出された酸化鉄 は焼結が進行して凝集している. 本工程までで得られたもの をJFE スチールでは「海綿鉄」と呼称している，海綿鉄は未 反応のコークスと石灰も含まれる状態となっている。 そのた め, 粉砕と磁選により鉄濃度を高めた粉末とする。この粉砕 粉は, アトマイズ工程で得られた生粉同様, 粉末治金用とし て用いるには酸素量と炭素量が高すぎるため, 続く還元熱処 理工程で更に酸素量と炭素量を低減する，上述のように一部 の用途では海綿鉄を粉砕したものを出荷する場合もある.

\section{4 還元熱処理工程}

アトマイズ工程で得られた生粉および粗還元工程で得られ た海綿鉄粉碀粉（以下原料鉄粉）は，その炭素量や酸素量が 高く硬質なため，粉末治金用途には適さない。そこで，還元 熱処理炉による脱炭および還元処理を行う.

還元熱処理炉の構造を Fig. 5 に示す．基本的な構造は， ス テンレスベルトによって加熱対象を炉内へ搬送するベルト炉 である．原料鉄粉は，ステンレスベルトの上に厚み数十 $\mathrm{mm}$ 程度の層状（鉄粉充填層）に乗せられ，ベルトにより炉内へ 搬送されてゆく，炉体は複数のゾーンから構成されており， 役割ごとに加熱帯, 均熱帯および泠却帯と区別されている. 炉内は水素雾囲気であり䨌囲気ガスは炉の出側から入側に向 かって原料鉄粉の進行方向とは逆に流れている，炉内では以 下に示す 3 式の反応が進行する.

$$
\begin{aligned}
& \mathrm{Fe}_{3} \mathrm{C}+\mathrm{H}_{2} \mathrm{O} \rightarrow 3 \mathrm{Fe}+\mathrm{H}_{2}+\mathrm{CO} \\
& \mathrm{FeO}+\mathrm{H}_{2} \rightarrow \mathrm{Fe}+\mathrm{H}_{2} \mathrm{O} \\
& \mathrm{N}\left(\text { 鋼中) }+3 / 2 \mathrm{H}_{2} \rightarrow \mathrm{NH}_{3}\right.
\end{aligned}
$$

加熱帯では (4)の反応を促進させるために水素に加えて水 蒸気が導入される. 西田ら ${ }^{10)}$ によれば脱炭反応は還元反応が 進む $900^{\circ} \mathrm{C}$ 以上よりも低い, $820^{\circ} \mathrm{C}$ 近傍にピークがあるとさ れる. また, 多量の水蒸気は還元反応を阻害するため, 原料 鉄粉の温度が比較的低い加熱带にて水蒸気を導入し，還元反 応前に脱炭反応をほぼ完了させた方が効率的に脱炭と還元を 行える.

加熱帯に続く均熱帯では(5)に示される水素による酸化鉄 の還元反応が生じる. 式からも分かるように, 還元反応によ り $\mathrm{H}_{2} \mathrm{O}$ が生じる. 上述のように, 鉄粉充填層近傍の $\mathrm{H}_{2} \mathrm{O}$ 濃 度が高くなってしまうと還元反応の進行が遅滞する。そのた め, 水素を炉の出側から入側に向かって流すことで入側に向 かう気流を生じさせ鉄粉充填層から発生した $\mathrm{H}_{2} \mathrm{O}$ を速やか に加熱帯側へ排出させる. 加熱帯に侵入した $\mathrm{H}_{2} \mathrm{O}$ は脱炭反 


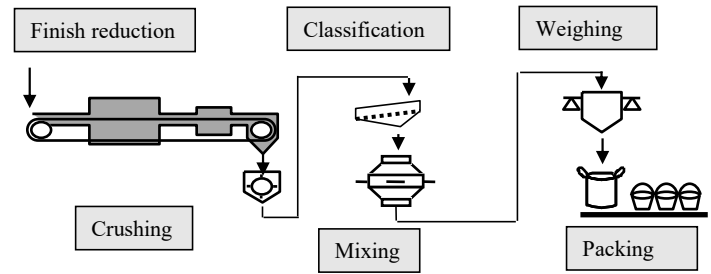

Fig. 6 Finish reduction, crushing, classification and packaging process.

応促進に寄与したのち，炉外へと排出される.

冷却带では鉄粉充填層の泠却が行われるとともに，(6)に 示される脱窒反応が進行する． $\mathrm{O}$ や $\mathrm{C}$ 同様， $\mathrm{N}$ についても鉄 粉の硬度を増加させ，これにより圧粉成形を困難とするた

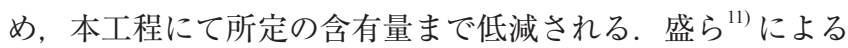
鋼板を用いた検討では，水素雲囲気での脱窒は 700 $720^{\circ} \mathrm{C} て ゙$ 最も進行するとされている，そのような点で, (6)の反応は, 温度の高い加熱带よりも，むしろ冷却の過程で鉄粉充填層の 温度が $700^{\circ} \mathrm{C}$ 近傍となる，冷却带にて進行すると考えられて いる.

還元熱処理炉を含む還元熱処理工程の概略図を Fig. 6 に示 す. 脱炭，還元および脱窒反応が終了し炬の出側から排出さ れた鉄粉充填層は，加熱により焼結し粒子が㠜集しているた め, 続く粉砕工程にて再度粉末化する. 更に, 粉砕工程で粉 末化できなかった粗い凝集粉を節分けにより除去して，粉末 治金に使用可能な高度に成分調整がなされた鉄粉が得られ る。還元熱処理工程㧍よびそれに続く粉砕工程は，鉄粉の粒 子形状に影響を及ぼす。また，その後の分級工程で最終的な 製品の粒度がほほ決定する。そそのような意味で，粉挽，分級 を含む還元熱処理工程は，成分調整だけでなく最終的な鉄粉 の粉体特性を決定する重要な工程であると言える．本工程後 の鉄粉はそのまま粉末治金用途やその他用途として出荷する 場合もあるが，粉末治金用の場合は後述の偏析防止処理を施 して出荷されることが多くなっている.

\section{5 真空還元工程}

粉末治金用の合金鋼粉は多様なニーズに応えるために様々 な成分調整が行われる，その中で，水アトマイズ時の溶鋼の 段階で MnやCr といった焼き入れ性の高い添加元素を加え ている粉種が存在する。これらの元素は標準生成自由エネル ギーが低い安定な酸化物を形成する ${ }^{22}$ ため，水アトマイズ時 にこれらの酸化物が生成すると水素雲囲気中での熱処理では 還元が難しい，そのため，合金鋼粉中に固溶させた C を還 元剤とした真空還元を行う.

本還元処理について，例として還元郕を Cとした場合の $\mathrm{Cr}$ 酸化物の還元反応を考える. 本反応については炭化物を 経由する詳細な反応式が提案されている ${ }^{13)}$ が，簡略化したも のを(7)に示す.

$$
\mathrm{Cr}_{2} \mathrm{O}_{3}+3 \mathrm{C} \rightarrow 2 \mathrm{Cr}+3 \mathrm{CO}
$$

Cr は高温では酸化しやすいため, 本反応による還元を進 めるためには前提として䨌囲気中の酸素分圧が低いことが必 要である。また, 反応時に生成した $\mathrm{CO}$ ガスの雾囲気中濃度

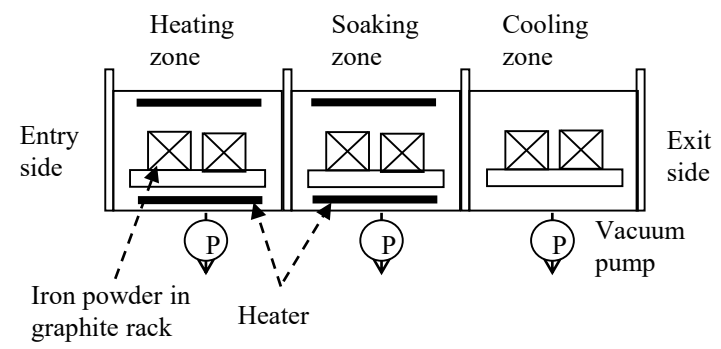

Fig. 7 The structure of vacuum reduction furnace.

が増加すると (7) の還元反応が遅滞する，そのため，真空排 気と同時に熱処理を行うことで雾囲気中の酸素分圧低下と, 生成ガスである $\mathrm{CO}$ ガスの排出の両方を達成でき, $\mathrm{Cr}_{2} \mathrm{O}_{3}$ の ような安定な酸化物の還元が可能となる。

上記のような還元処理を行う炉の例としてJFE スチールの 真空還元炉の構造を Fig. 7 に示す. 本炉の特徽は加熱室, 均 熱室, 冷却室の 3 つから構成されるセミバッチ式の自動炉と いう点 ${ }^{14)}$ であり，これにより高い生産性を実現している。 レイに充填された原料粉はまず加熱室内に搬送され，加熱さ れながら減圧される。所定の加熱温度, 真空度に到達した時 点で扉を開放し，均熱室へと搬送される。均熱室内で所定の 温度と時間保持されたのちに冷却室へと搬送され，ガス冷却 された後に炉外へ排出される．排出された鉄粉は加熱によっ て焼結し粒子が凝集しているため, 還元熱処理後と同様に粉 砕扔よび分級を行う。本工程後の鉄粉についても，水素中で の還元熱処理後の鉄粉と同様にそのまま出荷する場合と後述 の偏析防止処理を行う場合の 2 種類がある.

2.6 偏析防止処理工程

一般に粉末治金用の鉄粉は焼結部品としたときの強度を高 めるために黒鉛粉，銅粉及びその他合金粉末，プレス成形後 の成形体の金型からの離型性を高めるために潤滑剤を混合し て用いる。これらの粉末のうち特に鉄粉と黒鉛は大きく比重 が異なるため, 混合後長期間保管していると比重差に起因す る重量偏析を生じる ${ }^{15)}$.また，黒鉛は比重が小さいため混合 粉をハンドリングする際に発塵し易いという問題もある。こ れらの問題を解決するために混合の際に偏析防止処理を行う ことがある。

偏析防止処理粉の粒子構造を Fig. 8 に示す．鉄粉粒子表面 にバインダを介して黒鉛粉や銅粉等の合金粉末を付着させて いる。 これにより，圧粉成形時に偏析に起因する部品の寸法 や強度のバラつきが抑制され，更に発塵による粉末使用時の 環境対策などが不要となる。このような偏析防止処理粉は鉄 粉メーカー各社で商品化されている ${ }^{16-18)}$.

JFE スチールの偏析防止処理設備を Fig. 9 に示す。主原料 である鉄粉と各種の添加剤が充填されたホッパーを有してお り，そこから要求配合に応じて必要な量を一混合単位分ごと に精度良く切り出す。その後，ミキサーにて混合を行う。こ の時に，鉄粉表面にバインダを介して黒鉛などの添加剤が付 着される．混合された粉末は排出された後にフレキシブルコ ンテナに梱包され，出荷される. 


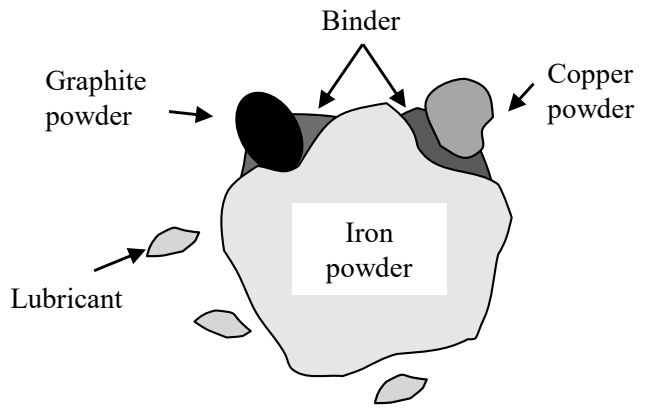

Fig. 8 Schematic description of the segregation-free pre-mixed iron powder.

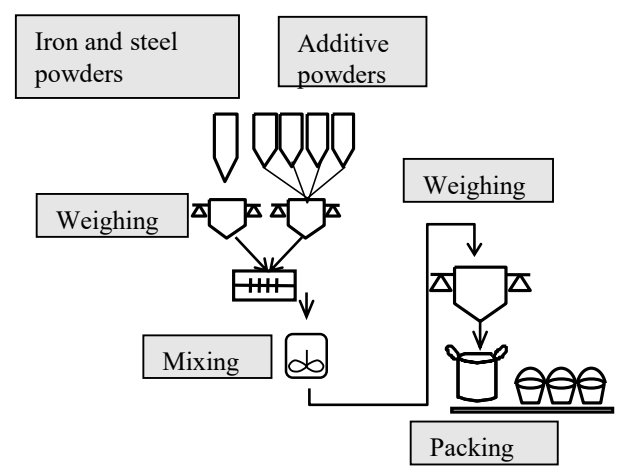

Fig. 9 Manufacturing process of segregation-free pre-mixed iron powder.

粉末治金の特徵は粉体を原料とすることで金属・非金属を 問わず，さまざま原料を混合できる点にある。そのような特 徵を生かし偏析防止処理工程では圧粉, 焼結後の部品の切削 性を改善する添加剤 ${ }^{19-22)}$ や，压粉体の強度を高めることで圧 粉状態での加工が可能となる添加剤 ${ }^{23)}$ が添加されることもあ る。また，混合粉末の流動性を改善することで複雑形状の金 型へも均一に充填が可能な偏析防止処理粉等も提案されてい $3^{24,25)}$.

\section{3 水アトマイズ法および還元法で得られる鉄粉の特徴}

\section{1 純鉄粉}

JFE スチールが製造する代表的な水アトマイズ純鉄粉 JIP ${ }^{\mathrm{R}}$ $300 \mathrm{~A}$ 抢よび還元鉄粉 JIP ${ }^{\circledR} 255 \mathrm{M}$ の化学成分抢よび粉末特性

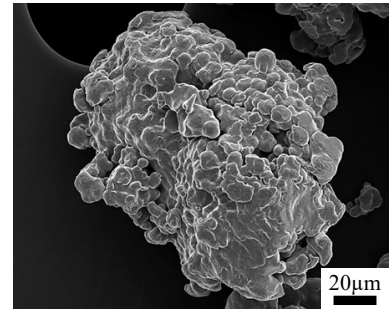

(a) Water atomized iron powder

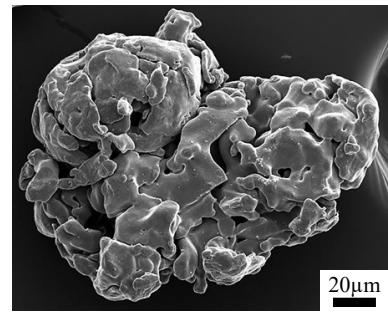

(b) Reduced iron powder
Fig. 10 Particle shapes of water atomized and reduced iron powders.

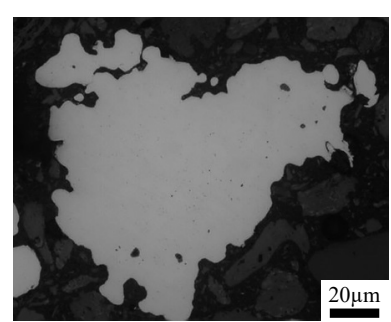

(a) Water atomized iron powder

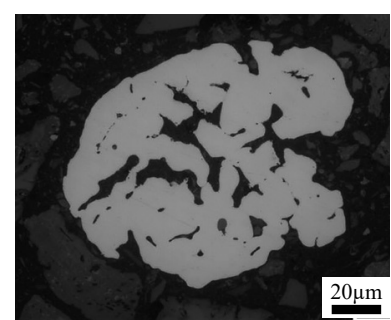

(b) Reduced iron powder
Fig. 11 Cross sections of particles of water atomized and reduced iron powders.

を比較したものを Table 2 抢よび 3 に示す ${ }^{26}$. 重量基準のメ ジアン径 $\mathrm{D}_{50}$ はほぼ同等であるが，見掛密度は $300 \mathrm{~A}$ の方が 高い。また，成分に着目すると C はほぼ同等であるが $\mathrm{O}$ は 255M の方が高い，成形体の圧粉密度は 300A の方が高い，

上記のような特性差を理解するために，更に鉄粉粒子の 形状と断面構造を比較したものを Fig. 10 および Fig. 11 に示 す．鉄粉粒子の外観はいずれも不定形であり，300A と 255M で大きな差はみられない。一方でその断面の組織は大きく異 なっており，300Aが稠密であるのに対し，255M は多孔質 となっている。このような多孔質構造が形成されるのは, 酸 化鉄の還元過程で鉄のウィスカーが生成，成長するためであ ると言われている27)。そのため, $255 \mathrm{M}$ の粒子内に存在する 気孔の多くは表面と槃がっている開気孔となっている，金属 粉の表面は大気と接することでわずかに酸化していると考え られ，そのため同じ粒子径であっても表面積が大きい $255 \mathrm{M}$ の方が Oの含有量は高くなっていると考えられる。また，

Table 2 Chemical compositions of water atomized and reduced iron powders ${ }^{24)}$.

\begin{tabular}{lllllll}
\hline & \multicolumn{1}{c}{ mass\% } \\
\hline $300 \mathrm{~A}$ & $\mathrm{C}$ & $\mathrm{Mn}$ & $\mathrm{Si}$ & $\mathrm{P}$ & $\mathrm{S}$ & $\mathrm{O}$ \\
\hline $255 \mathrm{M}$ & 0.004 & 0.080 & 0.020 & 0.004 & 0.008 & 0.100 \\
& 0.010 & 0.220 & 0.040 & 0.006 & 0.011 & 0.210 \\
\hline
\end{tabular}

Table 3 Powder properties of water atomized and reduced iron powders ${ }^{24)}$.

\begin{tabular}{|c|c|c|c|c|c|c|c|c|c|}
\hline & \multirow{2}{*}{$\begin{array}{l}\text { Apparent density } \\
\qquad / \mathrm{Mg} \mathrm{m}^{-3}\end{array}$} & \multirow{2}{*}{$\begin{array}{l}\text { Flow rate } \\
\text { / } \mathrm{s}(50 \mathrm{~g})^{-1}\end{array}$} & \multirow{2}{*}{$\begin{array}{l}\text { Median diameter } \\
\qquad / \mu \mathrm{m}\end{array}$} & \multirow{2}{*}{$\begin{array}{l}\text { Green density* } \\
\qquad / \mathrm{Mg} \mathrm{m}^{-3}\end{array}$} & \multicolumn{5}{|c|}{ Particle size distribution / mass $\%$} \\
\hline & & & & & $+106 \mu \mathrm{m}$ & $+75 \mu \mathrm{m}$ & $+63 \mu \mathrm{m}$ & $+45 \mu \mathrm{m}$ & $-45 \mu \mathrm{m}$ \\
\hline $300 \mathrm{~A}$ & 2.95 & 26.0 & 77.0 & 6.86 & 27.8 & 23.7 & 9.6 & 14.9 & 24.0 \\
\hline $255 \mathrm{M}$ & 2.57 & 29.7 & 75.9 & 6.73 & 20.6 & 30.3 & 11.3 & 18.1 & 19.7 \\
\hline
\end{tabular}

*Compaction pressure: $490 \mathrm{MPa}$ 
Table 4 Characteristics of several alloying methods for sintered steels.

$\begin{gathered}\text { Pre-alloyed } \\ \text { steel powder }\end{gathered}$
Compressibility
Homogeneity of chemical
composition and microstructure

気孔を含む組織となっているため, 同一粒子径であっても 255Mの方が低見掛密度かつ低圧粉密度となったと推定される。

以上代表的な水アトマイズ鉄粉㧍よび還元鉄粉の特性を比 較したが，それぞれ成分と見掛密度を規定したいくつかのグ レードが存在し ${ }^{28)}$, 用途に応じてその中から適切な特性を有 する水アトマイズ純鉄粉や還元鉄粉が選定される。例えば, 還元鉄粉は多孔質であるということを利用して，気孔内に油 を含浸させる含油軸受等に用いられる，また，成形時の粒子 同士の絡み合いは見掛密度が低くなるほど強くなるため, 還 元鉄粉の方が水アトマイズ鉄粉よりもラトラー值と呼ばれる 成形体の欠け性の指標が良好である ${ }^{29}$. そのため, 焼結部品 の中でも特に形状が複雑で割れや欠けが懸念される場合は, 低見掛密度の還元鉄粉が用いられることがある。また表面積 が大きいため，化学反応用として用いる場合，還元鉄粉の方 が反応は起こりやすい.

水アトマイズ鉄粉は稠密であるため, 高密度, 高強度が要 求される焼結部品に用いられる。 また，近年注目されている SMC（Soft Magnetic Composite）コア（圧粉磁心とも呼ばれ る）として用いる場合，コア内の磁性体充填率が磁気特性に 大きな影響を及ぼし，一般的に充填率の高いものが志向され る，そのため，高密度の圧粉体が得られる水アトマイズ鉄粉 が多く用いられている

\section{2 合金鋼粉}

粉末治金法で作製される鉄基焼結体の多くは強度を高める ために各種合金化元素が添加されている，その原料である鉄 粉へ合金化元素を添加する方法は複数あり，それぞれの特徵 をまとめたものを Table 4 に示す

最も単純な手法は溶鋼へ合金化元素を添加し，アトマイズ によって得られる鉄粉そのものを合金化してしまう手法であ る.このようにして得られた合金鋼粉は完全合金鋼粉と呼ば れる．完全合金鋼粉を用いて得られる焼結体は燒き入れ性が 高く, 均一な微視組織が得られる。 その反面, 粉末の時点で 合金化してある程度硬質化しているため，プレス成形時に高 密度の成形体を得るのが困難となってしまう。また，本手法 はアトマイズ工程で合金化元素を添加するため，還元鉄粉に
は適用できない，CrやMoは完全合金化による粉末の圧縮性 低下が比較的小さい ${ }^{33)}$ ので，完全合金鋼粉の合金化元素とし て多く用いられている ${ }^{34,35)}$

一方，純鉄粉と合金粉を混合後に熱処理を施して，鉄粉 表面に合金粉を拡散付着させたものは部分合金鋼粉と呼ば れる.この手法はアトマイズ鉄粉，還元鉄粉問わず合金化 が可能である．部分合金鋼粉は表面こそ合金化により硬質化 しているものの，中心部は純鉄のままなので完全合金鋼粉と 比べ圧縮性が高く，合金でありながら高い密度の成形体を得 ることが出来る。一方で，焼結のみで合金を組織中に均一に 拡散させるのは難しく, 微視組織中に一部軟質な領域が残留 してしまうのが難点である。部分合金鋼粉としては Fe-4Ni$1.5 \mathrm{Cu}-0.5 \mathrm{Mo}$ 部分合金鋼粉が知られている. 本合金鋼粉は,

$\mathrm{Ni}, \mathrm{Cu}$ 抢よびMoを純鉄粉表面に拡散付着させた合金鋼粉 であり，圧縮性に優れ， $\mathrm{Ni}$ と $\mathrm{Cu}$ の比率を適正化することで 焼結前後での寸法変化が小さいという特徴を有する ${ }^{36}$. 一一方 で本合金鋼粉は合金添加量が多いため, 添加量を削減しつつ 強度特性を確保した合金鋼粉等の開発も進められている ${ }^{37}$.

また，合金粉末と純鉄粉を単純に混合して焼結後に合金化 する手法もある。本手法は粉末の状態では一切合金化されて いないため，高い圧粉密度が得られる，その反面，2．6で 述べたような比重差に起因する重量偏析が生じる可能性があ る.また，得られる焼結体の微視組織は部分合金鋼粉を用い た場合よりも更に不均一なものとなってしまう。類似の手法 で偏析防止処理と同様にバインダを用いて鉄粉表面に合金粉 末を付着させる方法も存在する.

このように合金化の手法には長所と短所が存在し，目的に 応じて種々の手法が選定される。また，上記の手法を組み合 わせて用いる場合もある。例としてJFE スチールが開発した ハイブリッド型Mo 系合金鋼粉 AH4515を紹介する．AH4515 （Fe-0.6Mo）の粒子構造を Fig. 12 に示す. AH4515は Moを 予合金と部分拡散合金で添加しており，その比率を調整する ことで成形時の高い圧縮性と, 比較的均一な焼き入れ微視組 織，更には Moの表層濃化による焼結促進効果が得られ，硬 質で面圧疲労強度の高い焼結体が得られる ${ }^{38}$. 


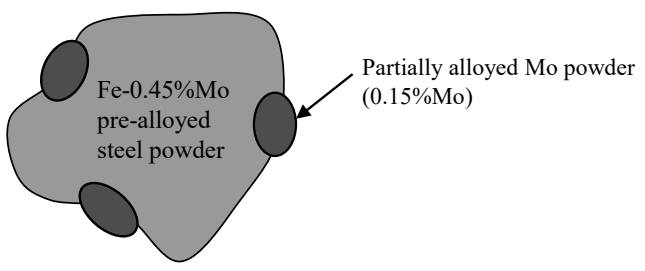

Fig. 12 Schematic description of the hybrid alloyed steel powder AH4515.

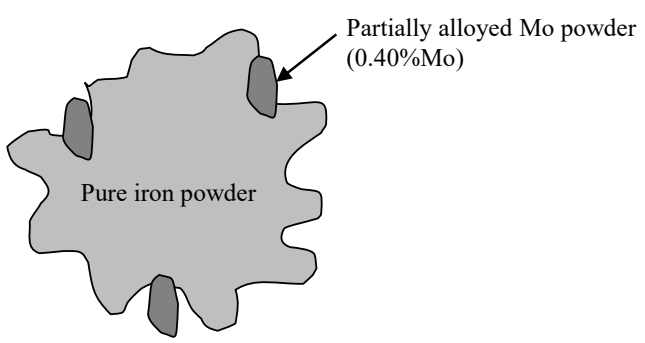

Fig. 13 Schematic description of the particle shape controlled alloyed steel powder SIGMALOY 4MO.

近年では合金成分および添加形態の適正化に加え, 粒子 構造制御にまで踏み込んだ高特性化も検討されている.JFE スチールが開発した焼結-浸炭熱処理工程向けの Ni フリー 高勒性合金鋼粉 FM1000S は, ベース粉である拡散付着合金 鋼粉シグマロイ ${ }^{\circledR} 4 \mathrm{MO}(\mathrm{Fe}-0.4 \mathrm{Mo})$ の粒子形状を不定形化 (Fig. 13）することで，Moの表層濃化および粒子比表面積増 加による焼結促進効果が得られ，焼結後の気孔が微細化す る.これにより従来の Mo 系合金鋼粉に比べて高い勒性と, 更には引張強さの増加も実現している ${ }^{39)}$.

\section{4 おわりに}

本解説では鉄粉の製造技術とその特徴について, 粉末治金 用の水アトマイズ鉄粉と還元鉄粉を中心に紹介した。しかし ながら冒頭でも述べたように，鉄粉はこのような粉末治金用 途に限らず, 化学反応用途（土㙵浄化, 海洋浄化, 脱酸剂, カイロ等), 磁性材料用途（ノイズフィルタ, インダクタ, モータコア，電磁弁等）等，様々な所で使用されている. また, 農業用, 3D プリンタ用等新しい用途も続々と開拓さ れている. 用途によって求められる特性は異なるが, 近年は 構造材から機能材へ用途が徐々にシフトしているようにも感 じ, それに応じて鉄粉に求められる品質も厳しくなってきて いる．鉄粉メーカーとしては従来用途のお客様の満足度を向 上させるとともに，新しい用途のニーズへ応えるために，従 来にない特性を持つ鉄粉とその製造技術開発へと挑戦してい きたい.

\section{文献}

1) R. M. German: Powder Metallurgy of Iron and Steel, JOHN WILEY \& SONS, INC. (1998) 30.

2) Japan Powder Metallurgy Association: 2018 Annual Report of JPMA, (2019) 4.

3) M. Kawamura, N. Okochi: Denki-Seiko, 80 (2009) 139-145.
4) T. Sawada, K. Yanagimoto: SANYO Tech. Rep., 9 (2002) 6469.

5) T. Maetani, J. Ohta, M. Fujinaga: JFE Tech. Rep., 36 (2015) 45-50.

6) K. Otsuka, K. Higuchi, A. Sonobe: JFE Tech. Rep., 36 (2015) 51-56.

7) M. Nitta, K. Ogura, S. Saito, H. Sugihara: Kawasaki Steel Tech. Rep., 24 (1992) 290-295.

8) Y. Morioka: Nishiyama Memorial Seminar, ISIJ, 82-83 (1982) 11-38.

9) Y. Yamamichi: J. Japan Inst. Met. Mater., 26 (1962) 754-759.

10) T. Nishida: J. Jpn. Soc. Powder Powder Metallurgy, 28 (1981) 1-7.

11) T. Mori, E. Ichise, Y. Niwa: Tetsu-to-Hagané, 58 (1972) $1264-$ 1279.

12) K. Mukai: Kagakunetsurikigakunotsukaikata, Kyoritsu-syuppan, (1992) 49-50.

13) N. Yamato, K. Ogura, E. Hatsugai, Y. Maeda: Kawasaki Steel Tech. Rep., 18 (1986) 270-276.

14) K. Higuchi, K. Akaoka, Y. Yamamoto, K. Komamura: Kawasaki Steel Tech. Rep., 24 (1992) 285-289.

15) K. Ogura: J. Jpn. Soc. Powder Powder Metallurgy, 44 (1997) 470-474.

16) Höganäs AB Catalog 0255HOGJP, (2012).

17) S. Nishida, F. Takayasu: KOBE Steel Eng. Rep., 59 (2009) 71-75.

18) T. Ono, Y. Ozaki: JFE Tech. Rep., 26 (2010) 60-54.

19) S. Furuta, Y. Taniguchi: KOBE Steel Eng. Rep., 59 (2009) 7680.

20) T. Maetani, S. Unami, Y. Ozaki: J. Jpn. Soc. Powder Powder Metallurgy, 59 (2011) 37-39.

21) S. Unami, T. Maetani, Y. Ozaki: Advances in Powder Metallurgy \& Particulate Materials, (2012) 62-70.

22) K. Nushiro, T. Maetani, T. Ono, Y. Ozaki: J. Jpn. Soc. Powder Powder Metallurgy, 65 (2017) 129-131.

23) S. Unami, J. Hirayama: Abstract of Spring Meeting of the Jpn. Soc. Powder Powder Metallurgy, (2017) 183.

24) Höganäs AB Catalog 0071HOGJP, (2012).

25) T. Ono, Y. Ozaki: JFE Tech. Rep., 36 (2015) 69-74.

26) T. Hayasaka: Nishiyama Memorial Seminar, ISIJ, 82-83 (1982) 43-65.

27) Y. Iguchi, S. Hayashi: Tetsu-to-Hagané, 79 (1993) 431-442.

28) JFE steel JIP Catalog J1J-001-03, (2015)

29) Y. Morioka: J. Jpn. Soc. Powder Powder Metallurgy, 22 (1976) 247-256.

30) H. Hojo, N. Akagi, T, Sawayama, H. Mitani: KOBE Steel Eng. Rep., 60 (2010) 79-83.

31) T. Takashita, N. Nakamura, Y. Ozaki: J. Japan Inst. Met. Mater., 79 (2015) 315-323.

32) K. Nishi, Y. Aono, K. Okamoto, T. Imagawa, K. Souma: J. 
Jpn. Soc. Powder Powder Metallurgy, 63 (2016) 63-69.

33) S. Miura, K. Takagi: Funmatsuyakinnokagaku, Uchidaroukakuho, (1996) 254

34) T. Maetani, S. Unami, T. Ono, Y. Ozaki, K. Ogura: J. Jpn Soc. Powder Powder Metallurgy, 61 (2014) 313-317.

35) S. Unami, Y. Ozaki, T. Ono: J. Jpn Soc. Powder Powder Metallurgy, 57 (2009) 140-142.
36) P. Lindskog: Powder Metallurgy, 56 (2013) 351-361.

37) O. Furukimi, K. Maruta, Y. Maeda: Kawasaki Steel Tech. Rep., 24 (1992) 273-278.

38) S. Unami, Y. Ozaki, T. Ushirozako, H. Tanino: J. Jpn Soc. Powder Powder Metallurgy, 57 (2010) 341-347.

39) T. Takashita, A. Kobayashi, T. Maetani, S. Unami: J. Jpn. Soc. Powder Powder Metallurgy, 67 (2020) 27-29. 